\title{
DOES RELIGIOUS ACTIVITY AFFECT CHILDBEARING DECISIONS? THE CASE OF GEORGIA
}

\section{Lasha Lanchava}

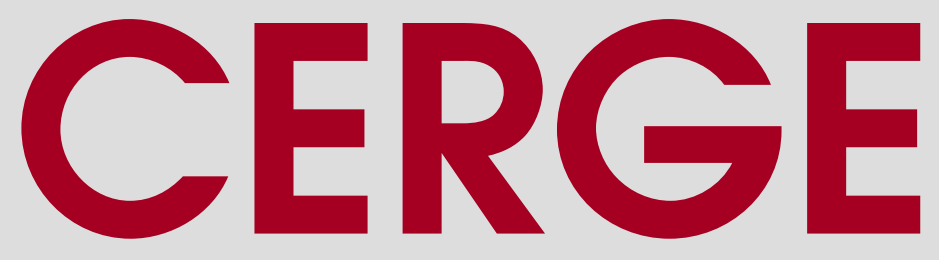

Charles University

Centerfor Economic Research and Graduate Education

Academy of Sciences of the Czech Republic

Ec onomic Institute 


\title{
Working Paper Series 521 (ISSN 1211-3298)
}

\section{Does Religious Activity Affect Childbearing Decisions? The Case of Georgia}

\author{
Lasha Lanchava
}

\section{CERGE-EI}

Prague, December 2014 
ISBN 978-80-7343-326-0 (Univerzita Karlova. Centrum pro ekonomický výzkum a doktorské studium)

ISBN 978-80-7344-318-4 (Akademie věd České republiky. Národohospodářský ústav) 


\title{
Does Religious Activity Affect Childbearing Decisions? The Case of Georgia*
}

\author{
Lasha Lanchava \\ CERGE-EI, Prague
}

\begin{abstract}
In response to the problem of shrinking birthrates in the country, in October 2007, the head of the Georgian Orthodox church announced that he would personally baptize any third and further baby born to Orthodox families from that time. This study uses the initiative as a natural experiment to explore the economic consequences of religious activity. This analysis uses individual level survey data from the Caucasus Resource Research Center (CRRC) Georgia on fertility before and after the initiative for Orthodox Christians (treatment group) and NonOrthodox Christians (control group) population to identify the effect of the church leader's promise on birth rates. Difference-in-differences estimation procedure is employed to examine the potential causal effect. This analysis does not find evidence that the church initiative had an effect on fertility.
\end{abstract}

\begin{abstract}
Abstrakt
V reakci na snížení porodnosti v zemi oznámila v říjnu 2007 hlava gruzínské pravoslavné církve, že bude osobně křtít každé třetí a další dítě, které se od té doby pravoslavným rodinám narodí. Tato studie používá jeho návrh jako přirozený experiment, jenž zkoumá ekonomické důsledky náboženské aktivity. Tato analýza používá jednotlivé úrovně dat o plodnosti $\mathrm{z}$ gruzínského výzkumného centra Caucasus Resource Research Center (CRRC) a vyhodnocuje porodnost na populaci pravoslavných křest’anů (léčebná skupina) a ostatních křest'anů (kontrolní skupina) před a po tomto návrhu. Má za úkol určit, v jaké míre byla porodnost slibem církevního otce ovlivněna. Metoda rozdílu v rozdílech (difference-in-differences) zkoumá potenciální kauzální efekt. Tato analýza nenachází důkazy, že církevní návrh porodnost ovlivnil.
\end{abstract}

Kewords: fertility, religion, Christianity, Difference-in-Differences, panel data JEL Classification: J13, Z120, C13

\footnotetext{
* Acknowledgments: I would like to thank Peter Katuscak and Patrick Gaule for extensive academic support. All errors remaining in this text are the responsibility of the author. The financial support of the Czech Science Foundation project No. P402/12/G097 DYME Dynamic Models in Economics is acknowledged.

CERGE-EI, a joint workplace of Charles University and the Economics Institute of the Academy of Sciences of the Czech Republic, Politických veznu 7, 11121 Prague, Czech Republic, Lasha.Lanchava@ @erge-ei.cz(corresponding author).
} 


\section{Introduction}

In 2007, the head of Georgian Orthodox church announced that he would personally baptize any third and further baby born to Orthodox families from that time in an effort to increase the dangerously low birth rates in the country. In March 2009 the BBC reported: "Church leader sparks Georgian Baby boom" and further "Two years after having one of the lowest birth rates in the world, Georgia is enjoying something of a baby boom, following an intervention from the country's most senior cleric". The results are, in the words of the Georgian Orthodox Church, "a miracle"."1 In the report we read that the number of births during 2008 increased nearly by $20 \%$ and the church officials claim that the major credit for the dramatic increase in birth rate must be attributed to Patriarch's announcement ${ }^{2}$. However, in the same report the head of Georgia's Civil Registry says that the noticeable increase in the birth rate is due to the economic boom. According to the National Statistics Office of Georgia birth rate per thousands of population increased from 11.2 in 2007 to 12.9 in 2008 , which is approximately a 15\% increase, whereas the birth rate from 2000 until 2007 had been fluctuating around 11. According to the same statistics, Georgia experienced remarkable growth in real GDP by about $10 \%$ in 2006-2007, which lessened in 2008 due to war with Russia but still remained significantly higher than in the previous years.

This study aims to empirically investigate whether church leader's initiative triggered considerable increase of birth rate in post 2007 Georgia. This analysis uses individual level survey data from the Caucasus Resource Research Center (CRRC) Georgia on fertility before and after the initiative for the Orthodox Christian (OC) (treatment group) and the NonOrthodox Christian (NOC) (control group) population to identify the effect of the church leader's promise on birth rates. Difference-in-differences estimation procedure is employed to detect any potential causal effect.

\footnotetext{
1 The information can be found at http://news.bbc.co.uk/2/hi/europe/7964302.stm .

${ }^{2}$ The report with similar sentiment was published by the CNN on April 2010. The source is available at : http://www.cnn.com/2010/WORLD/europe/04/23/georgia.powerful.patriarch.ilia/index.html
} 


\section{Literature Review}

This paper is related to two streams of literature. The first is the analysis of economic consequences of religious behavior. The origins of the study of religion as an important driver of socio-economic outcomes can be traced back to Max Weber's (1905) essay ${ }^{3}$ on the differences in per-capita GDP across Protestant and Catholic nations in Europe. McCleary and Barro (2003) show that countries with high levels of religious observance (i.e. attendance at religious services) experience lower GDP growth. However, according to the same study, increased belief in existence of hell and heaven imply higher GDP growth. Crabtree (2010), based on a Gallup poll across 114 countries, reports that the countries with highest frequency of religious population are those which have the lowest per-capita incomes. Lipford, McCormick and Tollison (1993) demonstrated that states with higher rates of church membership have significantly lower rates of violent and nonviolent crimes. According to Lehrer (2004) in the United States religion affects various social activities of individuals including divorce, marriage and fertility. Recent research in experimental economics explores the impact of religion on altruism and cooperation, as these studies through the lens of religiosity analyze the subjects' behavior in Dictator (Eckel \& Grossman, 2004; Tan, 2006), Public good (Anderson \& Mellor, 2009), Prisoner's Dilemma (Chuah, Hoffmann, Jones, \& Williams, 2011) and trust games (Bellemare \& Kroger, 2007; Johansson-Stenman, Mahmud, \& Martinsson, 2008) respectively (see Hoffman, 2012 for review).

The second stream of literature this paper related to is about the effects of persuasive communication on sales, voting behavior, charity contributions and investments (see DellaVigna \& Gentzkow (2009) for review of empirical evidence). Stark and Finke (2000) argue that observed relatively high fertility rates in Mormon populations can be explained by the fact that Mormon Church generously offers social approval and blessings to those

\footnotetext{
${ }^{3}$ The Protestant Ethic and the Spirit of Capitalism
} 
families who have many children and these offerings (or church recognitions) are greatly appreciated by the Mormon community.

This study aims to assess whether Patriarch's call, as Georgian clergy maintains, triggered the increase in birth rates in Georgia or if birth rates increased due to other factors which could involve improved aggregate social well-being. DellaVigna and Gentzkow (2009) claim that most important factor in the effectiveness of persuasion is personal contact. In the context of this paper, an agent, in this case the head of church, tried to influence the demographic outcome of the country and, he was personally involved in the persuasion campaign. Therefore this paper can also provide evidence for whether personal contact is an effective strategy in the persuasive communication.

\section{The Initiative and the Country of Georgia}

In October 2007 the head of the Georgian Orthodox Church, officially referred to as the Catholicos-Patriarch of All Georgia, announced that he would personally baptize any third and subsequent child born after the promise was made. The Patriarch is a highly influential and recognized authority among the Georgian population. According to the CRRC about $94 \%$ of the Georgian population considers him as the most trusted man in the society. As a result, at the end of 2008, he baptized almost 5000 infants at the main Sameba (Holy Trinity) Cathedral, and the tradition continues until today.

The announcement of the Catholicos-Patriarch's initiative can be considered a good natural experiment given the composition of religious population of Georgia. In particular, despite the majority of OCs who constitute $84 \%$ of the population, Georgia is also populated with NOC ethnic minorities such as Armenians, Azerbaijanis ${ }^{4}$ and other congregations. The

\footnotetext{
${ }^{4}$ Armenians are members of the Armenian Apostolic Church, while Azerbaijanis practice Islam.
} 
majority of NOC population is represented by Armenians and Azerbaijanis who comprise about $15 \%$ share of the population.

The OC population can be labeled adopters of the church initiative and NOC ethnic minorities can be described as non-adopters. The identifying assumption is that the number of births before the Patriarch's announcement followed a similar path across these groups. The latter argument allows for the application of difference-in-differences method to identify the impact of religious leader's initiative on the birth rates in Georgia.

\section{Data}

This analysis uses household level survey data provided by the CRRC Georgia. Among other household demographic characteristics, it contains information about how many babies families have and in which year they were born. It also contains information about parents' religious affiliation and the intensity of religious belief ${ }^{5}$. From the survey data I constructed two kinds of panel datasets. The first contains information about the birth rates in a given year. Table 1 depicts the summary statistics. The share of OC population in the dataset $(0.82)$ is very close to the national average $(0.85)$. The incidence of birth is constructed so that it is one if in a given year family has a child and is zero otherwise. Table 1 shows that the probability of having children and the age of the mother does not differ significantly across groups, though OCs report having a significantly higher measure of intensity of religious belief $(\mathrm{p}<0.001)$. Because the church initiative was targeted specifically for the third and subsequent children it is interesting to study its impact specifically on the targeted population of newborns. Therefore the second dataset was formed containing information about the

\footnotetext{
${ }^{5}$ There are two measures of the intensity of religious belief in the data. The first one is importance of religion which is a categorical variable on the scale of 1 to 4 . It equals one if religion is not important in respondent's life and four if religion is very important. The second measure is a level of religiosity of a respondent which is also a categorical variable on the scale of 1 to 10. It equals one if a person characterizes herself/himself as not religious and ten if a respondent considers self as very religious. The results in this analysis are based on the first measure of the intensity of religious belief. The results are identical if the second measure is used. These results are not reported here. They are available upon request.
} 
incidences of births of the third and subsequent children (See Table 2 for summary statistics). The latter dataset is constructed differently to the first one. In this case the households can only enter the data one year after the birth of their second child. For example, a family might have had a second child in 2005. In this case, the family participates in the data from 2006 onwards. If in any year, after 2006, a family had the third or subsequent child the incidence would be one, otherwise it would be zero. Those families who had only one child from 2000 to 2010 are not included in the data. Table 2 shows that there is no difference in terms of incidence of having a child across two groups but the age of the mothers and the reported intensity of religious belief is significantly higher in the OC population.

Table 1. Summary statistics for the sample for dataset 1.

\begin{tabular}{|c|c|c|c|c|c|}
\hline \multirow[b]{2}{*}{ Variable } & All & $\mathrm{OC}$ & \multicolumn{2}{|l|}{$\mathrm{NOC}$} & \multirow[t]{2}{*}{$\mathrm{P}$} \\
\hline & Obs Mean Std. Dev. & Obs Mean Std. Dev. & Obs Mean & Std. Dev. & \\
\hline Incidence of Having a Child & 238920.064 & 196130.0650 .247 & 42790.061 & 0.240 & 0.345 \\
\hline Age of Mother & $\begin{array}{lll}2172 & 25.18 & 7.863\end{array}$ & 25.237 .778 & 38924.98 & 8.247 & 0.580 \\
\hline Intensity of Religious Belief & 1.173 & 3.420 .601 & 2.61 & 2.234 & 0.000 \\
\hline
\end{tabular}

Notes: P shows statistical significance for two tailed t-test.

Table 2. Summary statistics for the sample for dataset 2 .

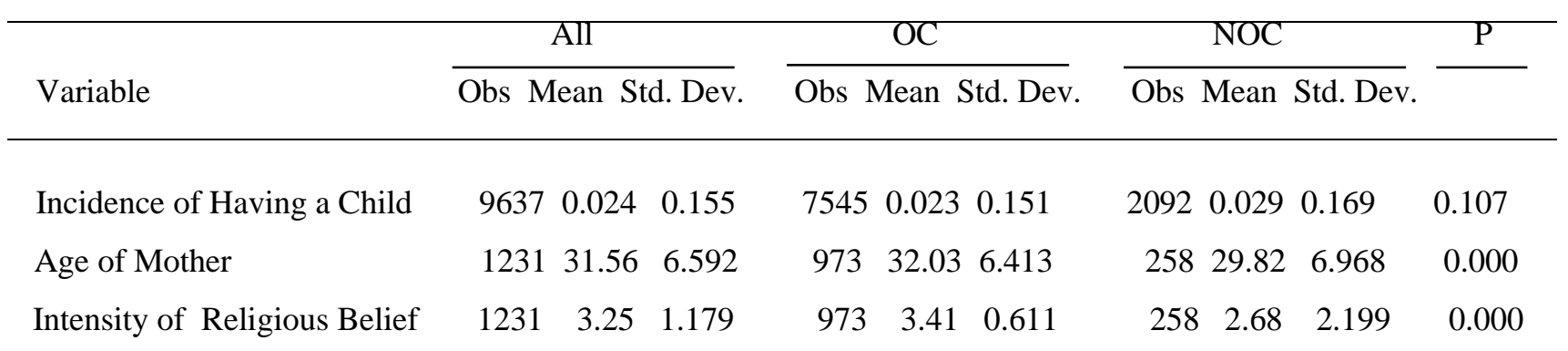

Notes: P shows statistical significance for two tailed t-test. 


\section{Empirical Analysis and Results}

\section{4.a. Main Results}

To estimate the impact of the Patriarch's initiative on the number of births, the difference-indifferences estimation procedure is used. Consider the following regression of the incidence rate for the period 2000-2010:

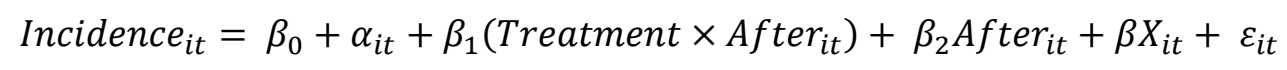

where $X_{i t}$ is the set of controls. After ${ }_{i t}$ is a dummy variable which equals 1 from year 2008. Treatment $i t$ is a dummy variable, which is one for OCs (treatment group) and zero otherwise (NOCs, control group). Treatment $\times$ After $r_{i t}$ is an interaction term which is supposed to measure the effect of the church leader's initiative on the birth rate. $\alpha_{i t}$ controls for household level fixed effects.

One of the main assumptions of difference-in-differences estimation is that the outcome variable follows the same trend for the treatment and control groups in the absence of the Patriarch's announcement.

Figures 1 and 2 depict the evolution of the birth rate over time for all and third and subsequent children respectively. As the figures show there is a significant divergence in the trends of outcome variable of the treatment and control groups in 2004-2006. 
Figure 1

Evolution of Birth Rate Over Time: All Chidren

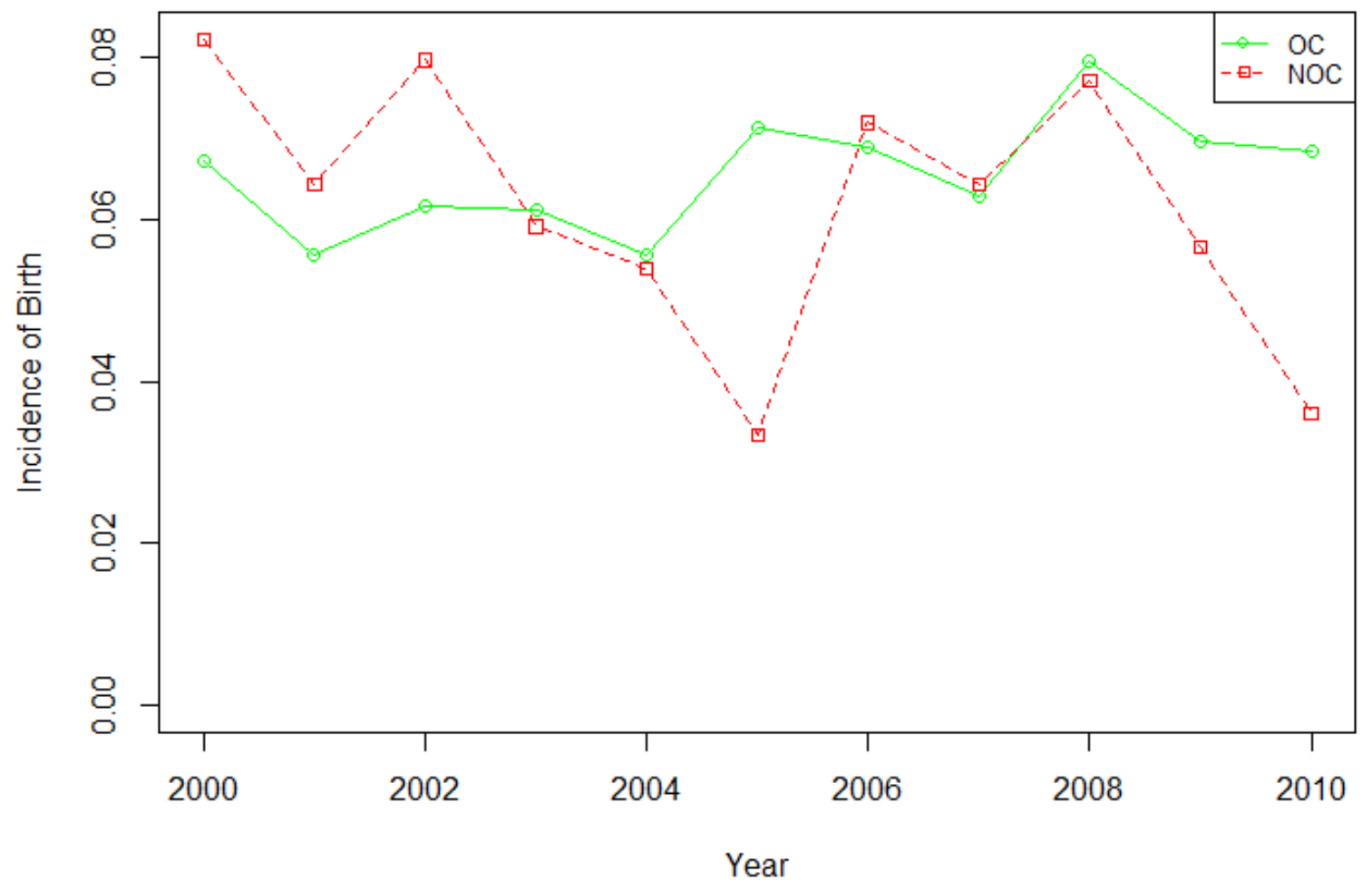

Figure 2

Evolution of Birth Rate Over Time: The 3rd and Subsequent Children

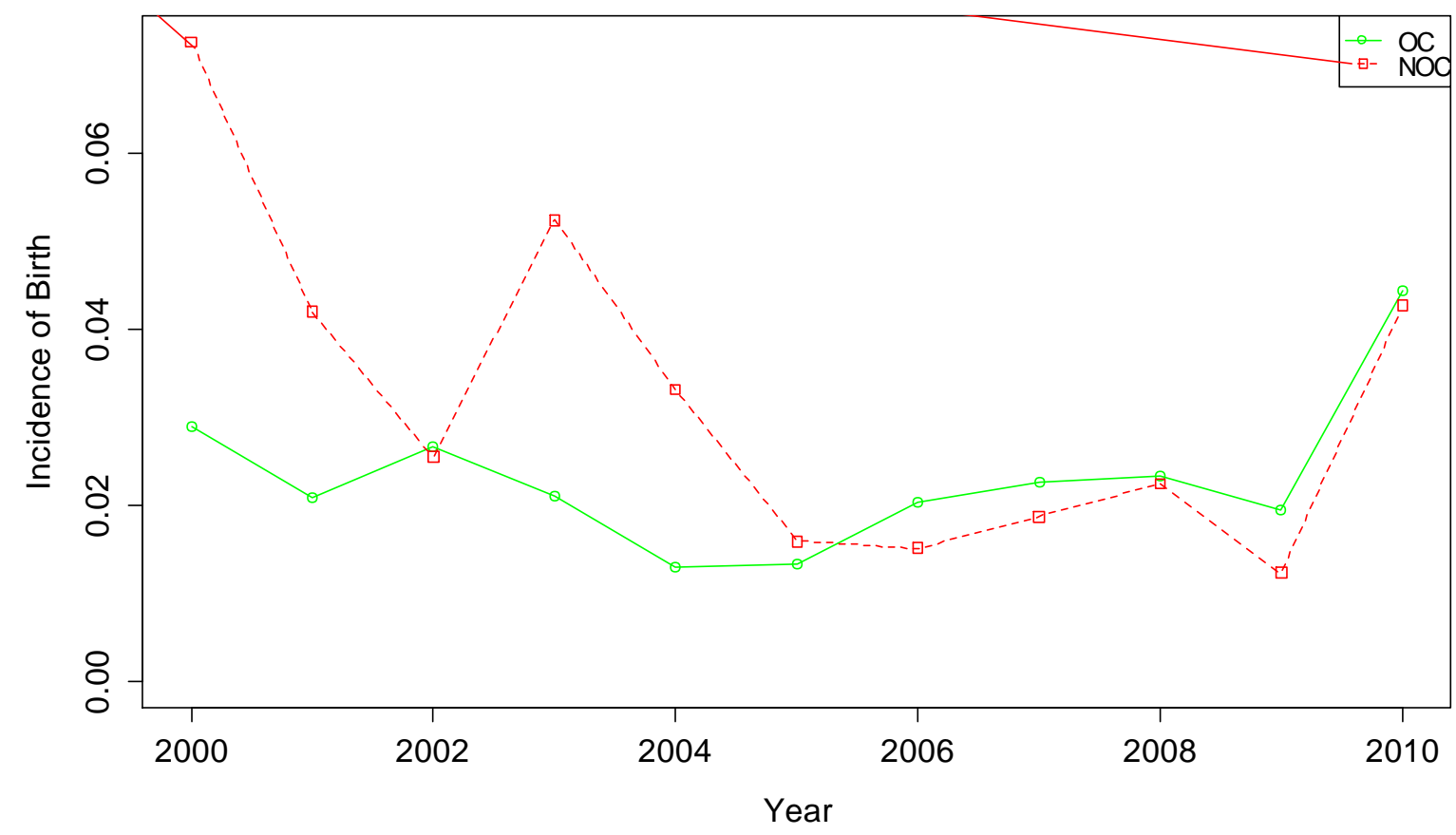


To account for the diverging paths of the outcome variable I controlled for time trend in equation (1) which becomes:

$$
\begin{gathered}
\text { Incidence }_{i t}=\beta_{0}+\alpha_{i t}+\beta_{1}\left(\text { Treatment } \times \text { After }_{i t}\right)+\beta_{2} \text { After }_{i t}+\beta X_{i t}+t_{i t}+ \\
t \times \text { Treatment }_{i t}+\varepsilon_{i t}
\end{gathered}
$$

Where $t_{i t}$ refers to the year.

The equation (2) was estimated while controlling for household level fixed effects. Standard errors were clustered at household level. Table 3 reports the estimation results for all children. Column (1) shows that the desired coefficient is negative but virtually zero in magnitude and statistically not significant. Column (2) displays the results of the regression while controling for available covariates. Including additional variables hardly changes either the size or the significance of the coefficient of interest. Perhaps intuitive observation is that mothers who had a child in previous the year are less likely to give a birth to another child in a given year. 
Table 3

The Impact of the Initiative on the Incidence of Having a Child: Dataset 1 Controlling for Household Fixed Effects

\begin{tabular}{lcc}
\hline \multirow{2}{*}{ Dependent Variable } & \multicolumn{2}{c}{ Incidence of Having a Child } \\
\cline { 2 - 3 } Treatment $\times$ After & $(1)$ & $(2)$ \\
& -0.005 & -0.006 \\
After & $(0.014)$ & $(0.014)$ \\
& 0.012 & $0.025^{*}$ \\
Mother's age & $(0.012)$ & $(0.013)$ \\
& & $0.007^{*}$ \\
Mother's age squared $\times 10^{-3}$ & $(0.004)$ \\
& & $-0.502^{* * *}$ \\
Parents had a child in a previous year & & $(0.000)$ \\
& & $-0.111^{* * *}$ \\
Constant & 0.660 & $(0.006)$ \\
& $(1.654)$ & $-42.343^{* * *}$ \\
Control for time trend & Yes & $(5.290)$ \\
& & $Y e s$ \\
\hline Observations & 23892 & 23892 \\
$\mathrm{R}^{2}$ & 0.0005 & 0.0237 \\
\hline Notes: Coefficients in all columns are OLS regression estimates, clustered standard \\
errors are in parentheses; $* * * * *$, and $*$ indicate significance at $1 \%, 5 \%$, and $10 \%$ \\
level, respectively.
\end{tabular}

Table 4 reports the estimation results of equation (2) in case of the third and subsequent children while controlling for household fixed effects. Column (1) shows a surprising negative sign of the coefficient of interest, though it is not statistically significant. I reestimated regression adding available controls as explanatory variables. As depicted in Column (2), the interaction term still has a negative sign and is not statistically significant indicating that church policies did not have an effect in case of the third and subsequent children either. This regression also shows that parents are more likely to have the third or subsequent child if the time which has passed since the birth of the last child is longer. 
Table 4

The Impact of the Initiative on the Incidence of Having $3^{\text {rd }}$ and Subsequent Child: Dataset 2 Controlling for Household Fixed Effects

\begin{tabular}{lcc}
\hline & \multicolumn{2}{c}{ Incidence of Having a Child } \\
\cline { 2 - 3 } Dependent Variable & $(1)$ & $(2)$ \\
\hline \multirow{2}{*}{ Treatment $\times$ After } & -0.012 & -0.011 \\
After & $(0.010)$ & $(0.011)$ \\
& $0.018^{*}$ & $0.019^{*}$ \\
Mother's age & $(0.010)$ & $(0.010)$ \\
& & $-0.015^{* * *}$ \\
Mother's age squared $\times 10^{-3}$ & & $(0.005)$ \\
& & -0.053 \\
Parents had a child in a previous year & & $(0.000)$ \\
& & $-0.148^{* * *}$ \\
\# of years passes since the birth of $2^{\text {nd }}$ child & $(0.016)$ \\
Constant & & $0.010^{* * *}$ \\
Control for time trend & $4.262^{* *}$ & $(0.003)$ \\
& $(1.733)$ & $-11.478^{* * *}$ \\
\hline Observations & Yes & $(3.238)$ \\
$\mathrm{R}^{2}$ & & Yes \\
\hline
\end{tabular}

Notes: Coefficients in all columns are OLS regression estimates, clustered standard errors are in parentheses; $* * *, * *$, and $*$ indicate significance at $1 \%, 5 \%$, and $10 \%$ level, respectively.

As shown above, a simple comparison of OC and NOC populations did not reveal a significant effect of the church initiative on fertility rates. The above analysis can be enriched by controlling for intensity of religious belief. Figures 3 and 4 depict the evolution of birth rate over time for groups with various intensity of religious belief for all and third and higher children respectively. Again, we see the similar picture of divergent trends of fertility. 
Figure 3

\section{Evolution of Birth Rate Over Time: All Chidren}

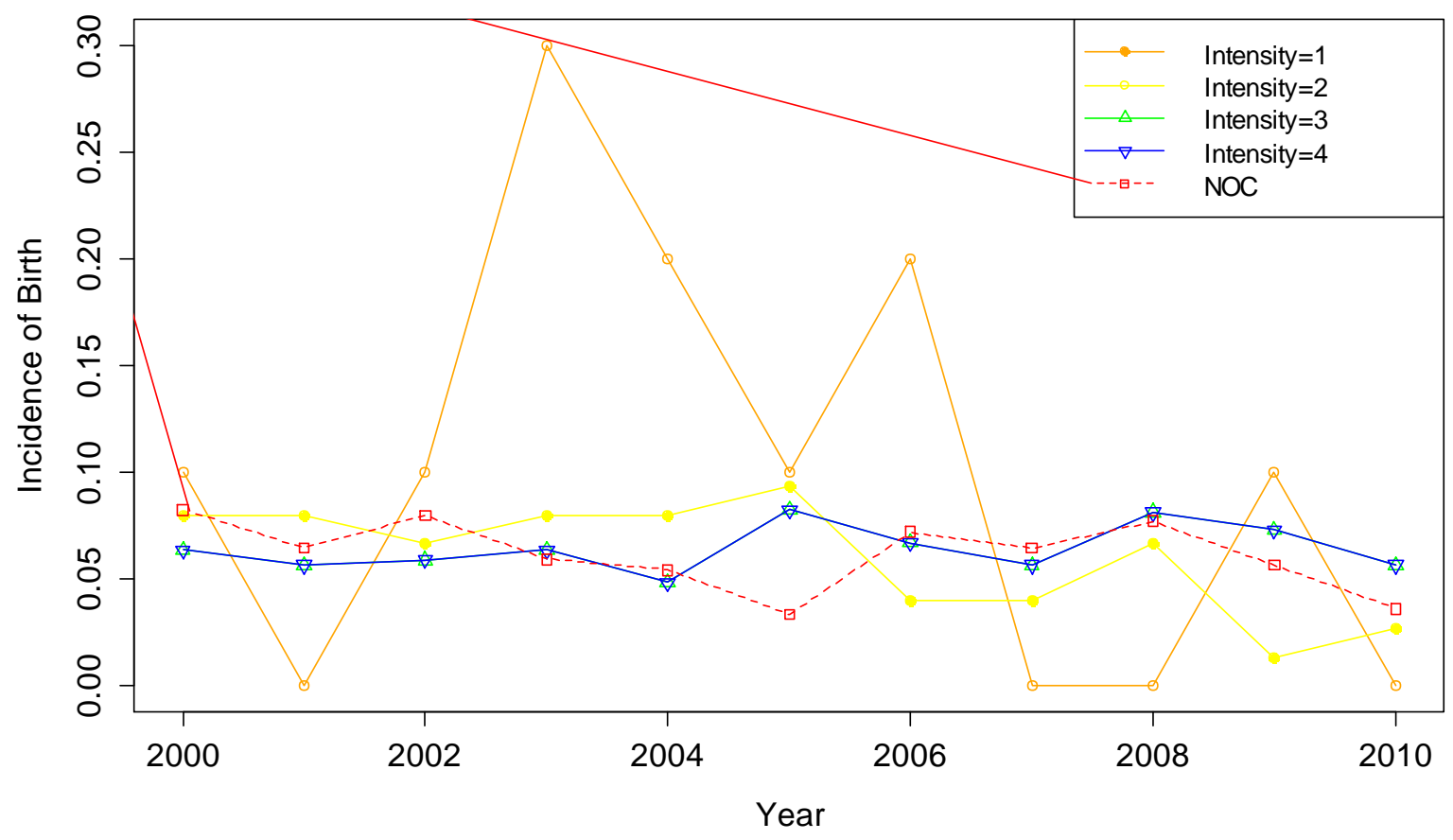

Figure 4

Evolution of Birth Rate Over Time: The 3rd and Subsequent Children

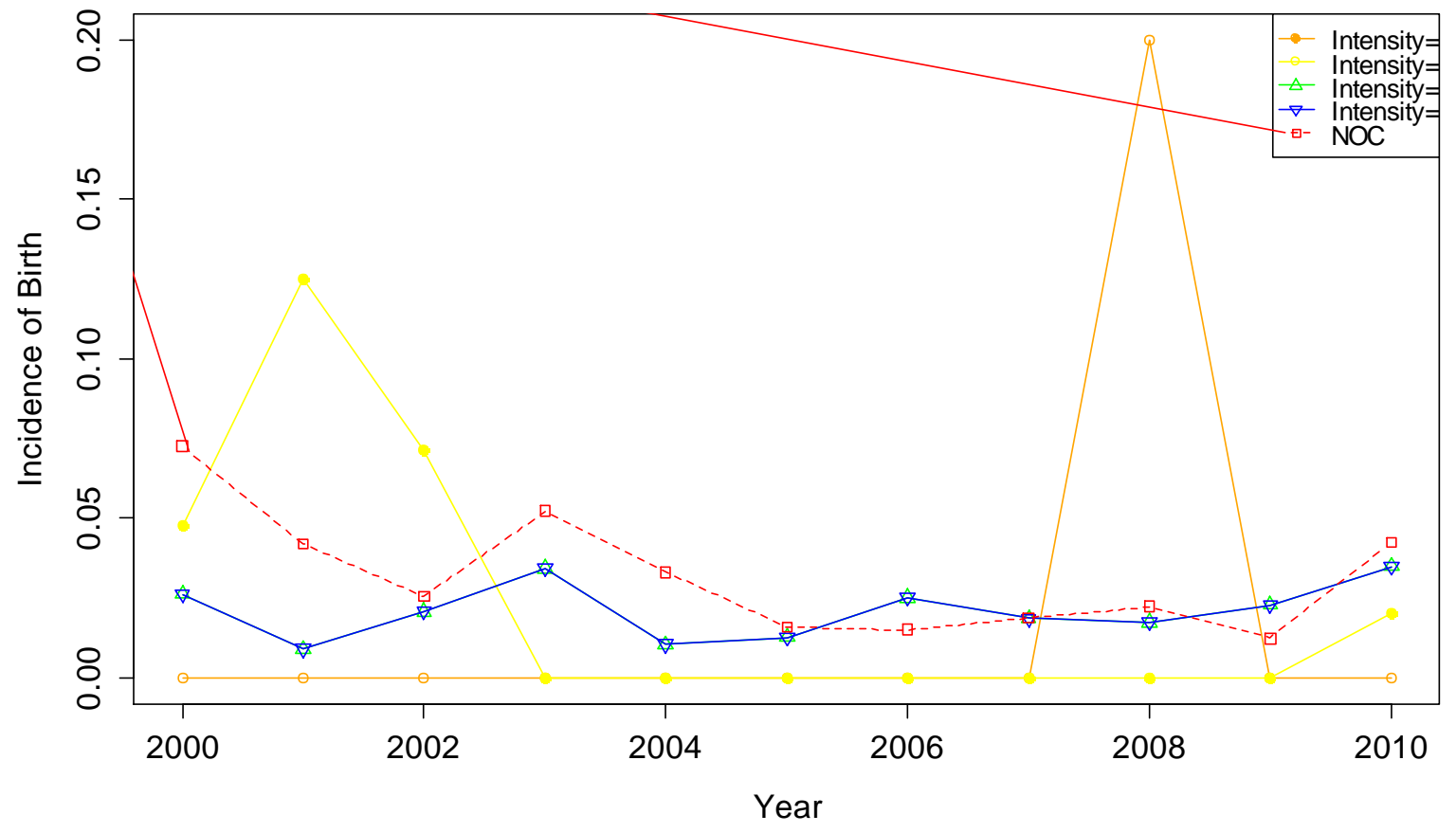

Therefore to account for diverging trends of the outcome variable I estimate modified version of equation (2): 


$$
\begin{gathered}
\text { Incidence }_{i t}=\beta_{0}+\alpha_{i t}+\beta_{1}\left(\text { Treatment } \times \text { After }_{i t}\right)+\beta_{2} \text { After }_{i t}+\beta X_{i t}+t_{i t}+ \\
t \times \text { Treatment }_{i t}+\varepsilon_{i t}
\end{gathered}
$$

Where Treatment $_{i t}$ in this case is a product of a dummy variable, which is one for OCs (treatment group) and zero otherwise (control group), and the measure of the intensity of a religious belief. Tables 5 and 6 report estimation results for all and third and subsequent children respectively. The results remain virtually unchanged and show that the church initiative did not have a statistically significant effect on birth rates in Georgia, either in case of all children or the third and subsequent children ${ }^{6}$.

One possible explanation for the non-result can be peer effects on fertility. That is, the Patriarch's announcement may have had an indirect effect on fertility norms among NOC groups. This is because if the NOC population observes their neighbors having more children, they may want to catch up. This spillover effect may decrease the significance of estimated coefficients. It may be also the case that Patriarch's announcement induced wide media coverage of the issue of fertility and thus affected OC and NOC groups equally by promoting higher fertility. These are valid concerns and there is no way to address them empirically. However, some specific facts about NOC groups in Georgia may throw light on the issue. First of all, the majority of NOC population live segregated in specific regions of country with little or no contact with the Georgian OC population. Therefore it is less likely that fertility peer effects could have been strong. Also, because among these NOC groups Azerbaijanis practice Islam and Armenians are members of the Armenian Apostolic Church it is not likely that the announcement of Orthodox Patriarch appealed to them. Finally, the

\footnotetext{
${ }^{6}$ It may be argued that religious leader's initiative would have stronger impact on marginal or lukewarm believers, because strong believers would have been expected to follow Patriarch's desire for having more babies anyway and they would not be required to change fertility decisions. If this is true, we should expect an inverted u-shape relationship between intensity of religious belief and strength of the policy effect and such inverted u-shape may be responsible for non-result. We performed similar analysis as in Table 5 and 6 for lukewarm believers only, but did not find evidence of statistically significant effect of church policy on the probability of having a child for this group either. The results are not reported here. They are available upon further request.
} 
majority of these groups are not literate in Georgian and therefore the effects of the Georgian media's coverage of fertility issue could not have found fertile ground among them.

Table 5

The Impact of the Initiative on the Incidence of Having a Child: Dataset 1 Controlling for Household Fixed Effects and Intensity of Religious Belief

\begin{tabular}{lcc}
\hline & \multicolumn{2}{c}{ Incidence of Having a Child } \\
\cline { 2 - 3 } Dependent Variable & $(1)$ & $(2)$ \\
\hline & & \\
Treatment $\times$ After & 0.003 & 0.002 \\
& $(0.003)$ & $(0.003)$ \\
After & -0.002 & 0.011 \\
& $(0.011)$ & $(0.011)$ \\
Mother's age & & $0.007^{*}$ \\
& & $(0.004)$ \\
Mother's age squared $\times 10^{-3}$ & & $-0.502^{* * *}$ \\
& & $(0.000)$ \\
Parents had a child in a previous year & 0.660 & $-0.111^{* * *}$ \\
& $(1.654)$ & $(0.006)$ \\
Constant & Yes & $(5.281)$ \\
Control for time trend & & $Y e s$ \\
& 23892 & 23892 \\
Observations & 0.0005 & 0.0237 \\
\hline
\end{tabular}

Notes: Coefficients in all columns are OLS regression estimates, clustered standard errors are in parentheses; $* * *, * *$, and $*$ indicate significance at $1 \%, 5 \%$, and $10 \%$ level, respectively. 


\section{Table 6}

The Impact of the Initiative on the Incidence of Having $3^{\text {rd }}$ and Subsequent Child: Dataset 2 Controlling for Household Fixed Effects and Intensity of Religious Belief Incidence of Having a Child

Dependent Variable

$\begin{array}{ll}\text { Treatment } \times \text { After } & -0.002 \\ & (0.003) \\ \text { After } & 0.016 \\ & (0.010)\end{array}$

Mother's age $-0.014 * * *$

Mother's age squared $\times 10^{-3}$

Parents had a child in a previous year

\# of years passes since the birth of $2^{\text {nd }}$ child

Constant

$4.245^{* *}$ $-10.906^{* * *}$

Control for time trend

Notes: Coefficients in all columns are OLS regression estimates, clustered standard errors are in parentheses; $* * *, * *$, and $*$ indicate significance at $1 \%, 5 \%$, and $10 \%$ level, respectively.

\section{4.b. Robustness check}

It might be argued that the NOC regions of Georgia enjoyed better economic conditions after 2007, which translated in higher incidence of births among the NOC population. This would in turn bias the coefficient of interest towards zero. To address this concern, it would be interesting to do the same analysis only for the capital city of Tbilisi, in which NOC ethnic minorities are disproportionally represented. Confining analysis to the capital city would potentially make similar trend assumptions more reasonable due to uniformity of socio economic factors that could influence birth incidence rates over time. Investigating the impact of church policy on birth rates for Tbilisi is interesting for another reason as well. As 
mentioned above, the baptism ceremony took place in main cathedral, which is located in Tbilisi. Therefore, mainly due to territorial proximity, one would expect that the effect of Patriarch's initiative would be stronger in the capital.

\section{Figure 5}

\section{Evolution of Birth Rate Over Time (Tbilisi): All Chidren}

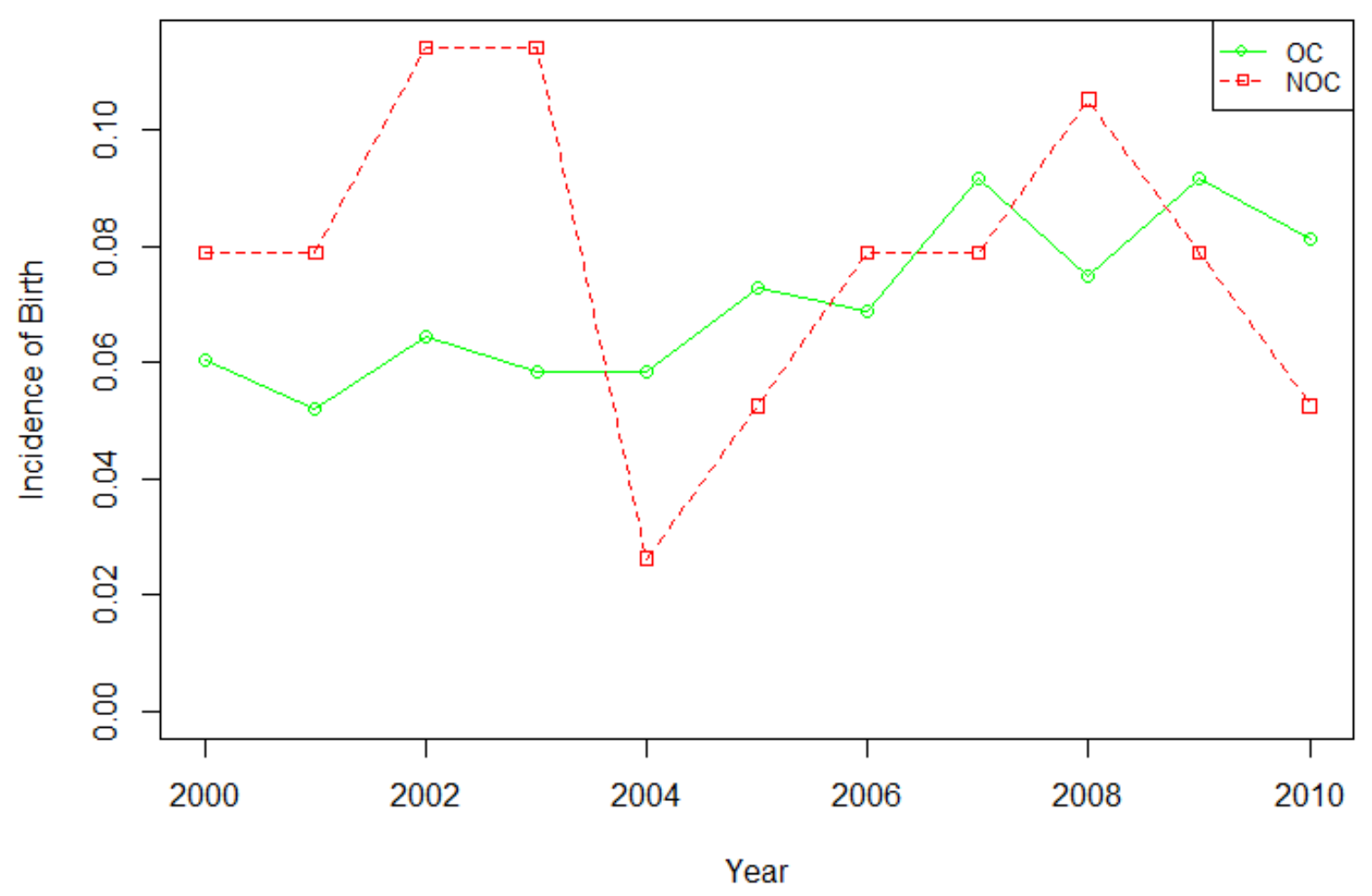

Figure 3 plots the evolution of the birth rate over time in Tbilisi for all children ${ }^{7}$. Again, it can be seen that there is a significant divergence in the trends of outcome variable of the treatment and control groups. Therefore, I estimated equation (2) controlling for time trend. Estimation results are presented in columns (1) and (2) in Table 7. Neither specification supports the case that the Patriarch's initiative had a statistically significant effect on birth rates.

\footnotetext{
${ }^{7}$ Robustness analysis was done for all children only. It was not possible to perform similar exercise for the third and subsequent children because of insufficient number of NOC families who actually had three or more children during the entire 11 years span.
} 
Table 7

The Impact of the Initiative on the Incidence of Having a Child (Tbilisi): Dataset 1

Controlling for Household Fixed Effects

\begin{tabular}{lcc}
\hline & \multicolumn{2}{c}{ Incidence of Having a Child } \\
\cline { 2 - 3 } Dependent Variable & $(1)$ & $(2)$ \\
\hline \multirow{2}{*}{ Treatment $\times$ After } & 0.009 & 0.008 \\
After & $(0.009)$ & $(0.009)$ \\
& -0.033 & -0.016 \\
Mother's age & $(0.031)$ & $(0.034)$ \\
& & 0.015 \\
Mother's age squared $\times 10^{-3}$ & & $(0.009)$ \\
& & $-0.559^{* * *}$ \\
Parents had a child in a previous year & & $(0.000)$ \\
& & $-0.141^{* * *}$ \\
Constant & -6.526 & $(0.010)$ \\
& $(3.406)$ & $-41.031^{* * *}$ \\
Control for time trend & Yes & $(12.388)$ \\
& & Yes \\
\hline Observations & 5698 & 5698 \\
$\mathrm{R}^{2}$ & 0.0019 & 0.0323 \\
\hline
\end{tabular}

Notes: Coefficients in all columns are OLS regression estimates, clustered standard errors are in parentheses; $* * *, * *$, and * indicate significance at $1 \%, 5 \%$, and $10 \%$ level, respectively.

Overall, despite the claims of the Orthodox Church of Georgia, this analysis does not support the idea that the Patriarch's initiative had a statistically significant effect on the birth rate of either all or the third and subsequent children. The results stay robust if the analysis is performed for the capital city only.

\section{Conclusion}

Following the Catholicos-Patriarch of All Georgia's initiative in October 2007, Georgia experienced an unprecedented baby boom starting from 2008. According to Georgian Orthodox clergy, the major credit for increased numbers of birth must be attributed to church intervention. Given the composition of the religious population of Georgia, this study uses the Patriarch's call as a natural experiment to study the impact of religion on the number of 
births. Analyzing the household level data on the incidence of births by using difference-indifferences estimation procedure revealed no statistically significant effect of the initiative on the dramatically increased birth rates. Despite the fact that the Patriarch was in personal contact with the beneficiaries of the initiative, the persuasion strategy did not seem to work in this case. Instead, the dramatic increase of birth rates could have been triggered by the improved economic conditions in Georgia. This may suggest that economic theories modeling fertility decisions on either micro or macro level should account for household economic situation as an important predictor variable.

One limitation of the study is the lack of very comparable control and treatment groups due to divergence in fertility trends between OC and NOC populations. Controlling for time trends does not completely solve this issue.

\section{References}

Anderson, L. R., \& Mellor, J. M. (2009). Religion and cooperation in a public goods experiment. Economics Letters, 105(1), 58-60.

Bellemare, C., \& Kröger, S. (2007). On representative social capital. European Economic Review, 51(1), 183-202.

Chuah, S. H., Hoffmann, R., Jones, M., \& Williams, G. (2007). Do cultures clash? Evidence from cross-national ultimatum game experiments. Journal of Economic Behavior \& Organization, 64(1), 35-48.

Crabtree, S. (2010). "Religiosity highest in world's poorest nations". Gallup's global reports.

Eckel, C. C., \& Grossman, P. J. (2004). Giving to secular causes by the religious and nonreligious: An experimental test of the responsiveness of giving to subsidies. Nonprofit and Voluntary Sector Quarterly, 33(2), 271-289.

Hoffmann, R. (2013). The Experimental Economics of Religion. Journal of Economic 
Surveys, 27(5), 813-845.

Johansson-Stenman, O., Mahmud, M., \& Martinsson, P. (2009). Trust and religion:

Experimental evidence from rural Bangladesh. Economica, 76(303), 462-485.

Lehrer, E. L. (2004). Religion as a determinant of economic and demographic behavior in the United States. Population and Development Review, 30(4), 707-726.

Lipford, J., McCormick, R. E., \& Tollison, R. D. (1993). Preaching matters. Journal of Economic Behavior \& Organization, 21(3), 235-250.

McCleary, R., \& Barro, R. (2003). Religion and economic growth across countries. American Sociological Review 68 (5), 760-781. 2003.

Stark, R., \& Finke, R. (2000). Acts of faith: Explaining the human side of religion. Univ of California Press.

Weber, M. (1958). “The Protestant Ethic and the Spirit of Capitalism”. New York: Scribner.

DellaVigna, S., \& Gentzkow, M. (2009). Persuasion: empirical evidence (No. w15298). National Bureau of Economic Research. 


\section{Working Paper Series}

ISSN 1211-3298

Registration No. (Ministry of Culture): E 19443

Individual researchers, as well as the on-line and printed versions of the CERGE-EI Working Papers (including their dissemination) were supported from institutional support RVO 67985998 from Economics Institute of the ASCR, v. v. i.

Specific research support and/or other grants the researchers/publications benefited from are acknowledged at the beginning of the Paper.

(c) Lasha Lanchava, 2014

All rights reserved. No part of this publication may be reproduced, stored in a retrieval system or transmitted in any form or by any means, electronic, mechanical or photocopying, recording, or otherwise without the prior permission of the publisher.

Published by

Charles University in Prague, Center for Economic Research and Graduate Education (CERGE) and

Economics Institute of the ASCR, v. v. i. (EI)

CERGE-El, Politických vězňů 7, 11121 Prague 1, tel.: +420 224005 153, Czech Republic.

Printed by CERGE-EI, Prague

Subscription: CERGE-EI homepage: http://www.cerge-ei.cz

Phone: + 420224005153

Email: office@cerge-ei.cz

Web: http://www.cerge-ei.cz

Editor: Marek Kapička

The paper is available online at http://www.cerge-ei.cz/publications/working_papers/.

ISBN 978-80-7343-326-0 (Univerzita Karlova. Centrum pro ekonomický výzkum a doktorské studium)

ISBN 978-80-7344-318-4 (Akademie věd České republiky. Národohospodářský ústav) 
CERGE-EI

P.O.BOX 882

Politických vězňů 7

11121 Praha 1

Czech Republic http://www.cerge-ei.cz 